\title{
JUURNAL.RU
}

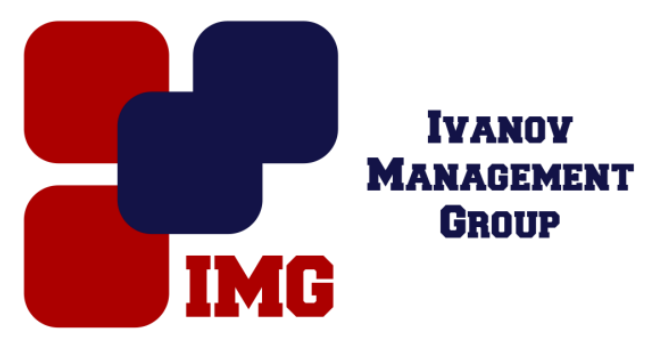

Кузьмина О.В.

Уральский государственный экономический университет Екатеринбург, Россия

doi: 10.18411/lj-31-07-2017-09

idsp 000001:1j-31-07-2017-09

\section{Роль волевых качеств личности в регуляции времени деятельности студентов}

\section{Аннотация}

В статье представлены результаты исследования различий, проявляющихся в организации времени деятельности и регуляции поведения у студентов, обладающих разными волевыми качествами. Определена роль отдельных волевых качеств в регуляции времени в процессе выполнения деятельности. Полученные данные помогут преподавателям в организации эффективного взаимодействия со студентом.

Ключевые слова: волевые качества личности, осознанная регуляция, регуляция времени деятельности, скорость, темп, планирование, моделирование.

В современных социальных и экономических условиях все больше становятся востребованными люди, обладающие волевыми качествами, способные проявлять инициативу и умения преодолевать трудности в ситуациях неопределенности, дефицита времени, умеющие самостоятельно организовывать свою деятельность. Самоорганизация во многом определяется волевыми качествами личности. Воля выступает сознательным регулятором поведения человека [2]. Она участвует в работе практических всех психических процессов. От степени ее сформированности зависит успешность деятельности. Волевая саморегуляция основывается на волевом усилии, которое направляет поведенческую активность в нужное направление. Ее функцией является повышение эффективности соответствующей деятельности. Волевое 
усилие предстает как сознательное, целенаправленное действие человека по преодолению внешних и внутренних препятствий. Замечено, что люди с недостаточно выраженной волевой регуляцией демонстрируют низкую трудоспособность, неумение сосредотачиваться на чем-то на длительный промежуток времени, неумение удерживать цели задания и определенную направленность действий, нестабильность в работе [1].

Одним из факторов, влияющих на проявление волевой регуляции, выступает время. Оно является не только внешней стороной организации деятельности, но и определяет внутренние характеристики личности, обуславливающие проявление своевременности, скорости деятельности [3].

По проблеме организации времени, развития воли и волевых качеств существует много разноплановых исследований как отечественной, так и зарубежной психологии и педагогики. Но чаще всего эти понятия не взаимосвязаны и освещены в разных направлениях. В представленном исследовании предпринята попытка связать проявление волевых качеств личности и временных характеристик выполнения деятельности, таких как своевременность, скорость, планирования, целеполагания.

Совместно с Е.Е. Виноградовой были изучены временные показатели деятельности, саморегуляция поведения и волевые качества личности 102 студентов Уральского гуманитарного института (УрГИ). Диагностика осуществлялась с помощью следующих методик «Опросник волевых качеств личности» (М.В. Чумаков), «Методика диагностики работоспособности» (Э. Ландольта), «Стиль саморегуляции поведения» (В.И. Моросанова). Обработка данных осуществлялась с помощью описательной статистики и критерия различий Н- Краскела-Уоллеса.

Анализ показателей времени, раскрывающих работоспособность студентов, позволил сделать следующие выводы. При высоких значениях инициативности $\quad(\mathrm{H}=7,67 ; \mathrm{p}<0,05), \quad$ самостоятельности $\quad(\mathrm{H}=7,19 ; \quad \mathrm{p}<0,05)$ возрастает скорость процессов переработки информации. Это свидетельствует о том, что студенты, обладающие данной характеристикой, способны обрабатывать достаточно большой объем информации. Они более успешны, чем другие при выполнении сложных алгоритмических операций, требующих быстрого реагирования и высокого темпа работы.

Такое качество как энергичность связано с точностью переработки информации $(\mathrm{H}=7,42 ; \mathrm{p}<0,05)$. Более энергичные студенты способны стабильно 
удерживать в сознании достаточно большой объем информации, погружаться в работу и своевременно предоставлять результаты своей деятельности.

Студенты, обладающие таким качеством как ответственность $(\mathrm{H}=6,22$; $\mathrm{p}<0,05)$, способны достаточно быстро перерабатывать информацию и быстро принимать решения, связанные с выполнением деятельности.

В результате анализа регуляции поведения с позиции планирования, моделирования и программирования своей деятельности были получены следующие закономерности. У инициативных ( $\mathrm{H}=10,12 ; \mathrm{p}<0,01)$, ответственных $(\mathrm{H}=6,11 ; \mathrm{p}<0,05)$ студентов сформирована потребность в осознанном планировании своей деятельности. А у энергичных ( $\mathrm{H}=10,55 ; \mathrm{p}<0,01)$, внимательных $(\mathrm{H}=6,36 ; \mathrm{p}<0,05)$, настойчивых $(\mathrm{H}=6,51 ; \mathrm{p}<0,05)$, ответственных $(\mathrm{H}=6,75 ; \mathrm{p}<0,05)$, обладающих выдержкой $(\mathrm{H}=9,34 ; \mathrm{p}<0,01)$ ярко выражены навыки моделирования своей деятельности как в настоящем времени («здесь и сейчас»), так и в перспективном будущем.

У студентов с такими качествами, как энергичность $(\mathrm{H}=10,74 ; \mathrm{p}<0,005)$, инициативность $(\mathrm{H}=6,60 ; \mathrm{p}<0,05)$, целеустремленность $(\mathrm{H}=6,42 ; \mathrm{p}<0,05)$, проявляющимися на высоком уровне, сформирована потребность продумывать способы своих действий для достижения намеченных целей, проявлять самостоятельность в разработке программ деятельности. Оценка и рефлексия своих результатов больше свойственна студентам с такими качествами, как ответственность $(\mathrm{H}=9,54 ; \mathrm{p}<0,01), \quad$ энергичность $(\mathrm{H}=8,27 ; \mathrm{p}<0,05)$. Они достаточно гибко адаптируются к изменяющимся условиям действительности, адекватно оценивают факт рассогласования полученных результатов с целью своей деятельности и пытаются определить и в дальнейшем его ликвидировать.

Осознанная регуляция своего поведения в большей степени сформирована у ответственных ( $\mathrm{H}=9,36 ; \mathrm{p}<0,01)$, настойчивых $(\mathrm{H}=8,39 ; \mathrm{p}<0,05)$, выдерженных $(\mathrm{H}=8,89 ; \mathrm{p}<0,05)$ студентов. Они самостоятельны, гибко и адекватно реагируют на изменения условий деятельности. Как показывают исследования, проведенные под руководством В.И. Моросановой, чем выше проявляется уровень осознанной саморегуляции, тем легче человек овладевает новыми видами активности, увереннее чувствует себя в незнакомых ситуациях, тем стабильнее его успехи в привычных видах деятельности [4].

У более энергичных $(\mathrm{H}=8,89 ; \mathrm{p}<0,05)$, инициативных $(\mathrm{H}=8,89 ; \mathrm{p}<0,05)$, решительных $(\mathrm{H}=8,89 ; \mathrm{p}<0,05)$ студентов сформирована пластичность всех регуляторных процессов. Гибкость регуляторных процессов позволяет адекватно реагировать на быстрое изменение событий и успешно решать 
поставленную задачу даже в ситуации риска. При возникновении непредвиденных обстоятельств они легко перестраивают планы и программы своего поведения.

Проведенное исследование позволило расширить знания о связи организации времени с личностными характеристиками и уточнить диапазон различий в проявлении регуляции временных показателей деятельности у студентов, обладающих разными волевыми качествами. Полученные данные полезны преподавателям высших учебных заведений при организации взаимодействия со студентами в индивидуальной и групповой работе.

$* * *$

1. Болотова А.К. Психология организации времени. - М., Аспект Пресс, 2006. - 254 с.

2. Ильин Е.П. Психология воли. - СПб.: Питер, $2009-368$ с.

3. Кузьмина О.В. Психология временной компетентности личности в жизненных ситуациях. - Екатеринбург: Информац-издат. центр Екатеринбургской епархии, 2017. - 204 с.

4. Моросанова В.И. Диагностика индивидуальных особенностей саморегуляции подростков// Прикладная психология. 2003. №3. С. 58-63. 